\title{
Employee Performance and Quality Management in the Tourism Sector (Case Study of Human Resources Management - Employee Performance)
}

\author{
Burhan Mahmoud Awad Alomari ${ }^{1}$, AlaEldin Mohammad Hasan Awawdeh ${ }^{1} \&$ Main Naser Alolayyan ${ }^{1}$ \\ ${ }^{1}$ Emirates College of Technology, HR Dept, Abu Dhabi, UAE Millennium Tower, Jordan \\ Correspondence: Burhan Mahmoud Awad Alomari, E mirates College of Technology, HR Dept, Abu Dhabi, \\ UAE Millennium Tower, Sheikh Hamdan Street, P. O. Box: 41009, Abu Dhabi, United Arab, Jordan. Email: \\ burhan.alomari@ect.ac.ae/alaeldin.awawdeh@ect.ac.ae/main.naser@ect.ac.ae/Faisalalzubi@hotmail.com
}

Received: March 29, 2017

Accepted: April 25, 2017

Online Published: August 4, 2017

doi:10.5539/mas.v11n9p1

URL: https://doi.org/10.5539/mas.v11n9p1

\begin{abstract}
The subject of quality is at the forefront of strategic plans for any business organization and institution to offer tourist services in the field of hotels. This becomes one of the priorities due to competition in reaching to the largest possible segment of customers. This is the need of time for the organization to master in quality, competencies and expertise in a variety of fields. The problem is how to manage quality for outstanding application in the service sector, tourism and hospitality by improving process and customer satisfaction.

This paper focuses on five stars hotel of the city of Aqaba, Jordan. The importance of this approach in general and tourism organization particular is very high. This study presents the descriptive analysis, limitation and treatment of change that represented by service diminution's. The importance of total quality management in the tourism sector is well understood. The study presents the managerial art that is applied in one of five star hotels as a $1^{\text {st }}$ degree of associate mixed company (Aqaba Hotel - Jordan). And I hope that the research modestly contribute to the performance of hotel organizations to meet the competitive challenges.
\end{abstract}

Keywords: performance management, employee engagement, talent management, personnel, working conditions

\section{Introduction}

\subsection{The Study}

The study aims to assess the reality of the application of total quality management in five stars hotels in Jordan. It focuses on the perceptions of employees responsible for applying the principles of total quality management. The duty of everyone in hotel is to ensure satisfaction of hotel customers at first. The management also needs to enable workers in the hotel to facilities of having the necessary skills. Resultantly, the outcome can enhance the hotel industry in Aqaba - Jordan and positively increase hotel income by providing the best services. This study aims to demonstrate the existence of significant differences in the adoption of workers and management to total quality management concepts, attributable to personal variables (experience, level of education, career, size). The study questionnaire was designed and distributed to a sample of staff and management who are working in the Aqaba hotel as a five star hotel in Jordan - Aqaba cities.

\subsection{Research Objectives}

The study aims to shed light on total quality management and employee performance. The tourism sector belongs to the workers and guests and is very important sector. The study has very significant objectives like what are major achievements in the tourist organizations, what are the elements of overall quality, and how to measure the extent of their application in the Tourism Hotel Company in Jordan.

\subsection{Research Problem}

The quality as subject is at the forefront of strategic plans for any services in public and private organization. The quality is the most important competitive precedent due to competition for reaching the largest possible segment of customers. The compliance of quality standards require capabilities, competencies and expertise in all areas. The research problem lies in how apply total quality management in the service sector (tourism and hotel), and 
how to improve service process and achieve internal and external customer satisfaction.

\subsection{Research Objectives}

The study of total quality management in the tourism sector has following research objectives as;

- To study the importance in the sector

- To find out the achievements of organizations in tourism

- To determine the overall quality elements in this sector

- To develop measurement of quality in hotel and tourism

- To investigate how to apply quality management in this sector

\subsection{Research Limitations}

The spatial boundaries of the company of Aqaba hotel in Aqaba city - Jordan presents mixed contribution. It is a first-class hotel, human borders represented employees in the company of Aqaba hotel and its guests. The temporal boundaries are from the year 2015-2016. The study questionnaire has been distributed to the staffs who are working in the hotel in order to gather the accurate information and generate valid results.

\section{The Method}

\subsection{Research Hypothesis}

The research assumes that there is application of six elements of TQM in the Aqaba Hotel Company, provides services and embodying six of overall quality elements. This will give opportunities and accuracy of satisfaction from their customers because of the best services and high quality according to competition in the market of tourism in Aqaba - Jordan.

\subsection{Questionnaire and Sample}

The questionnaire design is relying on the books and research theses on the subject of related research. The design of the study instrument also based on personal interviews with professors, specialists and managers of the commissioners in the company, number of officials, and field observations. It has included a questionnaire (44) questions are formulated on the Likert scale (Likert) Quintet (Zuelv, 1996.212), which describes the level of alternative anticipated responses in relation to every paragraph of the scale, as given five options are Totally Agree, Agree, Agree Somewhat, Disagree, Totally Disagree. The measurements are given statements with following grades as $1,2,3,4,5$, respectively. The questionnaire has been distributed simplerandomly to the hotel staff. The numbers of questionnaires were distributed after the review of three professors from the University of Jordan. Total 40where distributed to staff in the hotel company the total number of recovered and good for statistical analysis of them were 32 , with $80 \%$ response rate. The following table illustrates this:

\begin{tabular}{|c|c|c|c|c|c|c|c|c|c|c|c|}
\hline Gender & $\mathrm{t}$ & $\%$ & \multicolumn{2}{|c|}{ Age } & $\mathrm{T}$ & $\%$ & \multicolumn{3}{|c|}{ Educational attainment } & $\mathrm{T}$ & $\%$ \\
\hline \multirow[t]{2}{*}{ Male } & \multirow{2}{*}{18} & \multirow[t]{2}{*}{56.33} & \multirow{2}{*}{\multicolumn{2}{|c|}{$\begin{array}{l}\text { Less than } 25 \\
26-40\end{array}$}} & \multirow{2}{*}{7} & \multirow{2}{*}{$\begin{array}{l}21.9 \\
28.1\end{array}$} & \multirow{2}{*}{\multicolumn{3}{|c|}{$\begin{array}{l}\text { Reads and writes + elementary } \\
\text { Medium + PREP }\end{array}$}} & 3 & 9.4 \\
\hline & & & & & & & & & & 6 & 18.7 \\
\hline \multirow[t]{2}{*}{ Female } & \multirow[b]{2}{*}{14} & \multirow[t]{2}{*}{43.7} & \multirow{2}{*}{\multicolumn{2}{|c|}{$\begin{array}{l}55.41 \\
\text { Over } 56\end{array}$}} & 9 & 28.1 & \multirow{2}{*}{\multicolumn{3}{|c|}{$\begin{array}{l}\text { Institute + Bachelor } \\
\mathrm{MA}+\mathrm{PhD}\end{array}$}} & 12 & \\
\hline & & & & & 7 & 219 & & & & 12 & 34.4 \\
\hline \multirow[t]{6}{*}{ Total } & 100 & 32 & Tot & & 32 & 100 & Total & & & 32 & 100 \\
\hline & \multicolumn{3}{|c|}{$\begin{array}{l}\text { No of Years of } \\
\text { Service }\end{array}$} & $\mathrm{t}$ & $\%$ & & ccupation & $\mathrm{T}$ & $\%$ & & \\
\hline & \multicolumn{2}{|c|}{$7-1$} & & 7 & 21.9 & \multicolumn{2}{|c|}{ Head of dept. } & 11 & $\begin{array}{l}34.4 \\
4\end{array}$ & & \\
\hline & \multicolumn{2}{|c|}{$\begin{array}{l}14-8 \\
21-15\end{array}$} & & 12 & 31.2 & \multirow{2}{*}{\multicolumn{2}{|c|}{ supervisor }} & 5 & & & \\
\hline & \multicolumn{2}{|c|}{ Over 22} & & 8 & .219 & & & 16 & 50 & & \\
\hline & \multicolumn{2}{|c|}{ Total } & & 32 & 100 & & otal & 32 & 100 & & \\
\hline
\end{tabular}

The questionnaire is consisted of two parts. The first section is the general data related to the characteristics of 
personal and career: sex, age, educational attainment, years of service, function, and the second section of the questionnaire, is 39 related to elementscenters on hotel quality management, as the overall quality of the following:

\section{Literature and Review of Study}

\subsection{The Elements of Study}

- The first element: the hotel management support:

This element reflects the working environment and the actual practices at the hotel from the perspective of staff and ensures that paragraphs (1-14).

- The second element: continuous improvement:

This is developed in (5) paragraphs to measure this element represented by paragraphs (15-19).

- $\quad$ The third element: employee empowerment and work teams:

In order to measure, this element has been developed in (10) paragraphs; illustrate the extent of its application in the hotel, and those represented paragraphs (20-29).

- The fourth element: the motivation and reward performance:

This element, has been developed in (6), paragraphs represented (30-34) for measuring element.

- The fifth element: guaranteed quality of service:

This element has a set (5) paragraph represent (35-39).

\subsection{Performance of the Staff}

This has resulted in recognizing the importance of quality as a strategic weapon to achieve competitive advantage by adopting the philosophy of Total Quality Management (TQM). This philosophy is based on a set of ideas, strong quality orientation and the process of integrating functions of the organization to achieve the outstanding level of quality. The adoption of total quality management systems considers the overlap between all the elements of the organization, andincreases the effectiveness of the organization. Bakri (2000: 126) advocates for building the foundation for total quality management as a continuous improvement. Goal of TMS in this sector is guest orientation and to satisfy the visitors.Morgan \& Murgatroyd, (1994: 126) in their study, presented the followings:

\subsection{The area of service}

There are more business departments that provide more services than ever before. The growth of service-related tourism organizations is expanding as a result of the adoption of total quality management philosophy.

\subsection{Increased competition}

The business survival depends on access to adequate competition. TQM provides competitive advantages for thousands of tourist organizations specially hotels.

\subsection{Greater Understanding of Guests}

The encouragement for the guests of the services is perceived today more than ever before. Thequality products and reasonable prices are a favorite, but it is not everything. The customers want to be treated well, full respect for individuals and their participation in quality improvement.

\subsection{The Participation and Integration}

The participation and integration of all efforts in the tourism organizations in order to improve the quality of provided services. This improvement requires the powers necessary for authorization to carry out the process and satisfy the customer. There are three mentioned below advantages for the providers of TQM (Ghosh, 1998: 35 \& us, Eric, 1992).

\subsection{Competitive Advantage}

The equivalent of quality and price is needed for successfully managing a range of tourism products and services that meet specific needs.The advantage is achieved by providing the desired level of quality of the tourism product and services at a price that fits the capacity of the targeted visitors.

\subsection{The Service Level of Touring}

The expansion of the service level of tourism for tourists provides a number of benefits. It offers area of more choice of competition to the guests from the necessary adjustments in the event of a change in the tastes of the 
target market. The change in the conditions of service supply through diversification increase satisfaction of the tourists.

\subsection{Strategy}

The expansion of tourism products and services should not lead to high expense of competitive price and management effectiveness. It is necessary to formulate a strategy consistent with the quality of the presentation of tourism products (Naaman: 28).It should be strategic, flexible and adaptable to changes in the desires and tastes of the guests.It should also address the expected exchange rate, fluctuations and changes in the purchasing power of the targeted guests.

\subsection{Steps to Achieve Total Quality Management in Tourism Organizations}

The reception of tourists in the tourist sites requires familiarity with the great role required of the human element at the start and end of the tour. This also extends the role of the human element to include understanding of the needs and desires of tourists and create tourism environment surrounding satisfy to the fullest.The desire of achievingthe Millennium tourist is possible through quality in the service of tourists. There are a number of steps to be applied in this area: (Abu Rahma, et al, 2001: 81-86).

The Step one: The first step is to show a positive attitude towards others. The most of the workers fail in the field of guest service because of their position. The best thing in the service of visitors is to show a positive attitude to all who are dealing with them. The best way to show a positive attitude through the position that shows that person doing right the job. It mostly includes appearance that is one of the first impressions that are given to the guest.

1 - Body language: that can explain more than half of the message sent by the sender.

2 - Echo: it is often the tone of voice or how it is to say something more important than the words that are used.

3 - Phone: The most important skill is using the phone because that person has to experience the voice only. The person on the line with the customer is the sole representative of the organization.

Step Two: Identify the needs of guests that are determined by:

1 - Understand the time required for the quality of guest service: The knowledge of the requirements at the time of service is important in direct activity in providing high- quality service.

2 - Anticipate the needs of guests: This gives the service provider one step forward compared to the guests.

3 - Determine the needs of guests through the vigilance and kindness.Service provider vigilance is the skill to understand what guests might need and want.It goes further to provide service in a timely manner and beyond expectation.

4 - Identification of needs by understanding the basic needs of guests: There are four basic needs of the guests. They are need for understanding, a sense of welcome, the need for a sense of importance and comfort.

5 - Identify needs by getting feedback: each personnel at the hotel must be the provision of service to the guest to get a good feedback.

Third step: work to provide the needs of guests:

Quality of service can be provided by performing duties supporting the mission of organization. These duties include business inventory, configuration files, and record information etc. The success of the service provider depends on its ability to send clear messages. The clearance leads to the success or failure of the service provider to work.It must meet the basic needs of the guests that have been mentioned previously. Therefore, there is need of the practice of service through the active promotion of organized tourism services.

The organization needs to provide good service as a special challenge when the unexpected factor happens. This often puts unexpected additional burdens on the ability to provide a highly efficient service to the guest.

Fourth step: Make sure that the guests will return and this is done through:

1 - Enthusiasm for work.

2 - To do what can be done to satisfy those who complain.

3 - Learn how not to make guests nervous.

4 - Courage to take the extra step to provide the service by addressing the guests and go further than they expect of services.

The customer is the kind and services quality start and end with customer throughvarious activities. The activity 
starts with the meeting of customer needs, andends with him because they are buyer and consumer of this product and services.The process of evaluation will be by guests and customers. The satisfaction reported in assessment means the best product and services provided. This satisfaction is reflected in the increased sales followed by increasing profits (Naimi, 2000: 2).

There are key factors for the success of any business organization as tourist service providers. According to Adam and Ebort, (96: 601) they are:

1- The organization is a system to deal with external factors (customers and vendors) as elements that affect the quality. The organization must be approved by the foundation to achieve the wishes of the customers that are based on the quality objectives.

2- There are other factors affecting the success of SOA business organizations. The ranges of factors that affect the internal quality vary such as managers and workers, resources and the production process. The practices of total quality management applications in the tourism sector should focus on guest satisfaction and meet their needs.

The goal of TQM is to involve coordinated efforts of all employees to improve performance at all levels (Dilworth, 1992: 98). The management of the overall quality serves as a comprehensive commitment of doing business correctly. This commitment cannot be achieved if the performanceof employees away from standards (Atkinson, 1996: 40).

The case could be reached with good commitment through openness and trust among all staff. The most important for guests is the overall quality and the involvement of staff in the pursuit of continuous improvement (Warren shmedit 1997: 41). The important means of integration is to build a great team. The essence of this idea is to move away from the individual to act in the decision-making (Mark, 1995: 93). For the purpose of completion of the work quality of the team to the fullest to be interested in the active elements of the team, as shown in the following figure:

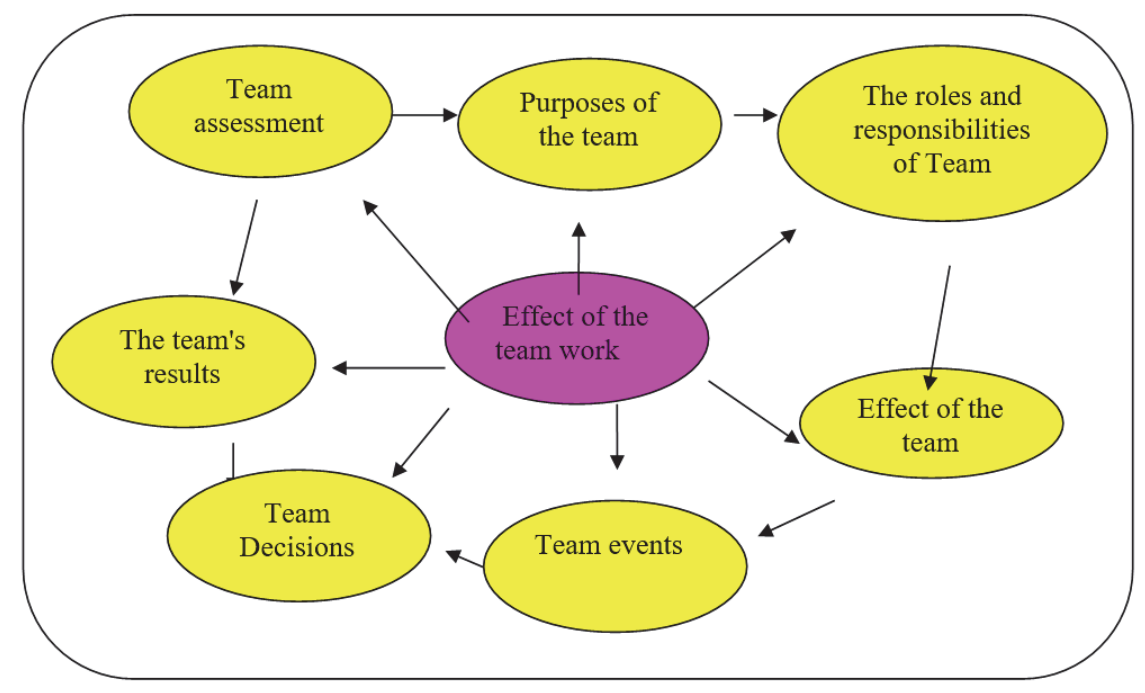

Source: Chapman \& Hall 1995, p: 102. Figure 1: team actors

The previous figure presents a clearer importance of work teams. The aim behind the formation of the team is that each individual contributes to his skill, experience and listen to others as others listen to his views. Organizations are in need of constant improvement of the quality of service and increased productivity, and these two elements need to be determinants of the team.

For business organizations, services (tourism) to designate and identify key needs of customers and the direct beneficiaries of its services (Haug \& Ken, 96:10). The granting of incentives to those who committed to quality and excellence, recording these achievements, recognition and rewards accordingly (David, 97: 12)

The application of total quality management in the hotel is to contribute to the hybrid Hotel of Aqaba. 


\section{Analysis and Results}

\subsection{Definition of Aqaba Hotel - Jordan}

Was established in 1973 and later updated nicely in the same city of Aqaba, Jordan which is located in the center of the resort city of Aqaba. It has wonderful views of the Red Sea and the rooms are decorated in a warm beautiful design with modern touches Arab coined. Guests can enter the private beach directly.

The Hotel of Aqaba, Jordan has excellent facilities, including children's activities center, a gym, swimming pools and outdoor. Diving trips can be arranged, as well as trips to Wadi Rum, Petra and the Dead Sea. The resort offers international cuisine throughout the day. Rooms at the hotel of Aqaba, Jordan are 296. Hotel in Aqaba, Jordan offers a restaurant, bar, reception service 24 hours, Newspapers, Garden, Terrace, Non-Smoking Rooms, Rooms / Facilities for Disabled Guests, Family Rooms, Elevator, Safety Deposit Box, Luggage Storage, Shops in Hotel, and Air-conditioning.

\subsection{Activities in the Hotel Aqaba Jordan}

The Hotel of Aqaba, Jordan has many activities like, sauna, fitness center, ski, Massage, Children's playground, table tennis, windsurfing, Joes, diving, scuba diving, and swimming pool outdoors.

\subsection{Services of the Hotel Aqaba Jordan}

The Hotel of Aqaba, Jordan Room Service, Meeting / Banquet, and the mode of transport to and from the airport, Business Centre, Babysitting / Child Services, laundry service, dry cleaning, Barber / Beauty Shop, VIP Room Facilities, Breakfast in the Room, Currency exchange, Gift Shop, Car Rental , Tour Desk , Fax / Photocopying, Ticket Service, Bank of automatic available. The numbers of employees are 315 workers, 300 Jordanian workers and $15 \mathrm{Arab}$ and foreign workers. Secondly the application of the elements of the overall quality in hotel of Aqaba is mix.

This research seeks to show results based on some of the methods and statistical tools for the study variables and paragraphs. The others aredistribution, recurring and percentages and the percentage of space measure for answers of respondents, circles computational variables and paragraphs in order determine the level of answers of all of them. The standard deviation for the diagnosis ranges dispersion values from their midst calculations and the results were as the following:

\subsection{Support the Management of the Hotel}

It is the first component of total quality management shows that there is a possibility for the management of the hotel to urge and encourage staff to accomplish the tasks assigned to them voluntarily. The attention to the customer needs to be given by understanding their needs and desires followed by doing the needful. The recalling the questionnaire for hotel staff (14) items each representing a sub-paragraph of the vertebrae senior management support of the hotel.

Table (1) shows the frequency distributions and percentages and the percentage of space and measure the values of community and standard deviations for the study sample answers.

The answers combined with research and general view show the level of application that supported the of element management of the hotel, with a mean year (3.68) degree and a standard deviation of (1.09). This indicates the existence of the application of the components of this element by the management of the hotel rises from the arithmetic mean hypothesis (3) and by space scale (73.7).

Table 1. Support the management of Aqaba hotels - Jordan -Aqaba, shows the frequency distribution, percentages, ratios and space scale values and deviations among staff responses to support an element of management in the Hotel

\begin{tabular}{llcccc}
\hline No. & $\begin{array}{l}\text { Paragraph } \\
\text { Support the management of hotels }\end{array}$ & $\begin{array}{l}\text { The middle } \\
\text { Arithmetic }\end{array}$ & $\begin{array}{l}\text { Deviation } \\
\text { Normative }\end{array}$ & $\begin{array}{l}\text { The } \\
\text { value } \\
\text { of }(\mathrm{t})\end{array}$ & $\begin{array}{c}\text { The level of } \\
\text { Significance } \\
\text { Spectator }\end{array}$ \\
\hline 1 & $\begin{array}{l}\text { Officials at the hotel do not stick to } \\
\text { their personal nor their views imposed } \\
\text { on staff. In the work. }\end{array}$ & 2.85 & 1.79 & -1.10 & 0.09 \\
2 & & & & \\
$\begin{array}{l}\text { The hotel management is seeking to } \\
\text { coordinate the activities of employees } \\
\text { in a way that helps to achieve }\end{array}$ & 3.69 & 1.14 & 7.87 & 0.00 \\
\hline
\end{tabular}




\begin{tabular}{|c|c|c|c|c|c|}
\hline & cooperation among themselves. & & & & \\
\hline 3 & $\begin{array}{l}\text { Hotel management is keen to cooperate } \\
\text { with the staff to ensure the wishes and } \\
\text { needs of guests }\end{array}$ & 4.00 & 0.96 & 13.49 & 0.00 \\
\hline 4 & $\begin{array}{l}\text { The hotel management has always } \\
\text { sought to achieve employee } \\
\text { satisfaction and loyalty }\end{array}$ & 3.96 & 1.00 & 12.44 & 0.00 \\
\hline 5 & $\begin{array}{l}\text { Hotel management is keen to find a } \\
\text { particular driver is characterized by the } \\
\text { hotel for the rest of the other hotels. }\end{array}$ & 3.81 & 0.98 & 10.80 & 0.00 \\
\hline 6 & $\begin{array}{l}\text { There is a program to involve the staff } \\
\text { in training sessions. }\end{array}$ & 3.81 & 0.98 & 10.80 & 0.00 \\
\hline 7 & $\begin{array}{l}\text { The hotel management is offeringwater } \\
\text { resources efficiently. }\end{array}$ & 2.48 & 1.18 & -5.28 & 0.00 \\
\hline 8 & $\begin{array}{l}\text { The hotel management is using human } \\
\text { resources in a keen way }\end{array}$ & 3.77 & 1.09 & 3.98 & 0.00 \\
\hline 9 & $\begin{array}{l}\text { The hotel management used scientific } \\
\text { methods to predict the numbers of } \\
\text { arrivals and their needs. }\end{array}$ & 2.7 & 1.87 & -8.85 & 0.00 \\
\hline 10 & $\begin{array}{l}\text { The hotel management is seeking to } \\
\text { avoid problems before they occur }\end{array}$ & 4.04 & 1.06 & 12.67 & 0.00 \\
\hline 11 & $\begin{array}{l}\text { Being job applicants tested prior to } \\
\text { their appointment. }\end{array}$ & 3.41 & 1.35 & 5.01 & 0.00 \\
\hline 12 & $\begin{array}{l}\text { Hotel management is keen to establish } \\
\text { good and lasting relations with the } \\
\text { tourism agencies and bodies in order to } \\
\text { attract a larger number of guests. }\end{array}$ & 3.74 & 1.28 & 4.72 & 0.00 \\
\hline 13 & $\begin{array}{l}\text { Hotel management is keen on attracting } \\
\text { specialized in hotel service staff. }\end{array}$ & 3.51 & 1.26 & 5.24 & 0.00 \\
\hline \multirow[t]{2}{*}{14} & $\begin{array}{l}\text { Hotel management creates and } \\
\text { facilities all necessary staff for } \\
\text { participation in the training program }\end{array}$ & 3.44 & 1.36 & 4.18 & 0.00 \\
\hline & Total & 3.47 & 1.79 & 3.00 & \\
\hline
\end{tabular}

The first hypothesis:

There are effective supports for the management of Aqaba Hotel. The table 01 shows that with the exception of paragraphs 1,7.9, all other paragraphs got among the calculation is greater than 3.00 and the levels of significance is less than 0.05 which is statistically significant. And replaced paragraph 10 came within the first rank and a mean of 4.04, followed by paragraph No. 3 in second place and a mean of 4.00, paragraph No. 11 it was ranked last among the paragraphs which is accepted statistically.

The paragraphs 1, 7.9, got among the calculation are less than 3.00 and all are not statistically significant. This means that the hotel officials cling to personal opinions and impose on staff. The hotel management do not use available financial resources in a good way and do not use scientific methods to predict the numbers of hotel guests and their needs.

The combined paragraphs have got to the middle of the account is greater than the 3.00 level of significance of less than 0.05 . They are statistically significant as the first to accept the hypothesis that there is an effective support for the management of Aqaba Hotel.The second hypothesis is continuous improvement in Aqaba Hotel.

Table 2. Presents continuous improvement in Aqaba Hotel:

\begin{tabular}{llcccc}
\hline No. & $\begin{array}{l}\text { Paragraph } \\
\text { Continuous improvement in Aqaba Hotel }\end{array}$ & $\begin{array}{l}\text { The middle } \\
\text { Arithmetic }\end{array}$ & $\begin{array}{l}\text { Deviation } \\
\text { Normative }\end{array}$ & $\begin{array}{l}\text { The } \\
\text { value } \\
\text { of }(\mathrm{t})\end{array}$ & $\begin{array}{l}\text { The level of } \\
\text { Significance } \\
\text { Spectator }\end{array}$ \\
\hline 15 & $\begin{array}{l}\text { Hotel management is keen on creating a } \\
\text { quick means of communication works to }\end{array}$ & 3.67 & 1.09 & 4.91 & 0.00 \\
\hline
\end{tabular}




\section{sustain an ongoing basis}

16 The hotel management encourages employees to make efforts to improve the quality of service provided initiatives.

17 The development of the hotel, Management constantly formats a suitable method of hotel work.

18 The hotel management rewards creations and innovations designed to improve the performance and service at a fair level.

19 Hotel management excludes excess procedures at work.

Total
3.97

0.74

10.76

0.00

4.18

0.63

15.42

0.00

1.56

5.21

0.18

3.66

1.03

6.49

0.00

According to Table2, with the exception of paragraphs 18, all other paragraphs got calculations greater than 3.00 and the levels of significance show less than 0.05 and statistically significant. The replaced paragraph No. 17 first came with a mean of 4.18 , followed by paragraph number 16 in second places and with a mean of 3.97 , and the last paragraph was No. 15 ranked within the paragraphs statistically acceptable.

Paragraph No. 18,got off the middle and less than 3.00 and statistically insignificant. This means that management does not reward creativity and no innovations designed to improve the performance and service and in a fair level.

The combined paragraphs have got to the middle and greater than the 3.00 level of significance of less than 0.05 which is statistically significant. The second hypothesis is accepted because there is continuous improvement in Aqaba Hotel.

The third hypothesis:

The employee and the team working improvement in the Hotel Aqaba enabled them to do the job.Table 03 presents results on employee empowerment and work teams to accomplish the performance

\begin{tabular}{|c|c|c|c|c|c|}
\hline No. & $\begin{array}{l}\text { Paragraph } \\
\text { Employee empowerment and work teams } \\
\text { to accomplish the performance }\end{array}$ & $\begin{array}{l}\text { The middle } \\
\text { Arithmetic }\end{array}$ & $\begin{array}{l}\text { Deviation } \\
\text { Normative }\end{array}$ & $\begin{array}{l}\text { The } \\
\text { value } \\
\text { of }(\mathrm{t})\end{array}$ & $\begin{array}{l}\text { The level of } \\
\text { Significance } \\
\text { Spectator }\end{array}$ \\
\hline 20 & Spirit of participation in decision-making & 3.93 & 1.02 & 9.33 & 0.00 \\
\hline 21 & $\begin{array}{l}\text { Staff at the hotel have the powers } \\
\text { necessary to perform their assigned work }\end{array}$ & 3.58 & 1.10 & 6.98 & 0.00 \\
\hline 22 & $\begin{array}{l}\text { The staff solving problems encountered } \\
\text { without reference to the direct } \\
\text { responsible person. }\end{array}$ & 2.65 & 1.44 & -0.67 & 0.50 \\
\hline 23 & $\begin{array}{l}\text { Team spirit prevails between the } \\
\text { employees and their colleagues. }\end{array}$ & 3.51 & 1.03 & 6.82 & 0.00 \\
\hline 24 & $\begin{array}{l}\text { Employees can contact supervisors at the } \\
\text { hotel is an easy way. }\end{array}$ & 3.39 & 1.20 & 4.95 & 0.00 \\
\hline 25 & $\begin{array}{l}\text { Managers and supervisors have taken the } \\
\text { opinion of the staff when making } \\
\text { important decisions. }\end{array}$ & 3.60 & 1.10 & 6.18 & 0.00 \\
\hline 26 & $\begin{array}{l}\text { Employees' is Proud of themselves and } \\
\text { their work in this hotel. }\end{array}$ & 3.46 & 1.22 & 4.50 & 0.00 \\
\hline 27 & $\begin{array}{l}\text { There is a formation of working teams, } \\
\text { especially when they are needed to } \\
\text { accomplish specific tasks }\end{array}$ & 2.59 & 1.57 & -1.65 & 0.10 \\
\hline 28 & $\begin{array}{l}\text { Staff at the hotel is linked to relations of } \\
\text { friendship and confidence among } \\
\text { themselves. }\end{array}$ & 3.86 & 1.07 & 8.58 & 0.00 \\
\hline 29 & $\begin{array}{l}\text { Hotel management has adopted an } \\
\text { open-door policy to enable employees to } \\
\text { put forward their ideas and suggestions }\end{array}$ & 3.53 & 1.19 & 5.15 & 0.00 \\
\hline
\end{tabular}




\begin{tabular}{|l|l|l|l|l|l|}
\hline & for the development of hotel service. & & & & \\
\hline & Total & 3.41 & 1.65 & 7.38 & 0.00 \\
\hline
\end{tabular}

The table 03 shows that with the exception of paragraphs 23.28, all other paragraphs got calculations greater than 3.00 and the level of significance is less than 0.05 which is statistically significant. The replaced paragraph No. 21 come with first rank and a mean of 3.93, followed by paragraph number 29 in second places and with a mean of 3.86, and was the last paragraph No. 25 the rank within paragraphs all are statistically acceptable.

The paragraphs No. 23.28, got calculations less than 3.00 and they are statistically insignificant too. The results show that employees are not solving the problems they are facing without reference to the direct responsible supervisor. They do not form teams when they need to accomplish specific tasks.

The combined paragraphs have got middle of the account and are greater than the 3.00 level of significance of less than 0.05 that is statistically significant. It leads to acceptance of the third hypothesis that there is ability of employees to handle the task forces in the Hotel Aqaba.

\subsection{Motivation and Reward Performance}

Table 04 includes frequency distribution, percentages, ratios and space scale values and the divisions among the responses to staff motivation and reward element of performance in Aqaba Hotel:

\begin{tabular}{|c|l|c|c|c|c|}
\hline No. & $\begin{array}{l}\text { Paragraph } \\
\text { Employee empowerment and work } \\
\text { teams to accomplish the performance }\end{array}$ & $\begin{array}{l}\text { The middle } \\
\text { Arithmetic }\end{array}$ & $\begin{array}{l}\text { Deviation } \\
\text { Normative }\end{array}$ & $\begin{array}{l}\text { The value } \\
\text { of }(\mathrm{t})\end{array}$ & $\begin{array}{l}\text { The level of } \\
\text { Significance } \\
\text { Spectator }\end{array}$ \\
\hline 30 & $\begin{array}{l}\text { The employee gets a cash bonus at } \\
\text { the completion of his particular job. }\end{array}$ & 4.15 & 0.70 & 12.05 & 0.00 \\
\hline 31 & $\begin{array}{l}\text { The procedures in the hotel don't get } \\
\text { delayed to give the required rewards } \\
\text { employee deserve. }\end{array}$ & 3.09 & 1.34 & 1.05 & 0.00 \\
\hline 32 & $\begin{array}{l}\text { Employees are keen to appreciate and } \\
\text { praise his responsibilities at work } \\
\text { when he completed a specific job. }\end{array}$ & 3.71 & 1.01 & 4.09 & 0.50 \\
\hline 34 & $\begin{array}{l}\text { Bonuses awarded in a fair way. } \\
\text { Hotel management is interested to } \\
\text { involve employees in decisions } \\
\text { relating to motivation and reward } \\
\text { system. }\end{array}$ & 2.81 & 0.69 & -.116 & 0.00 \\
\hline & & & 0.09 & 0.00 \\
\hline
\end{tabular}

The table above shows that the exception of paragraph No. 32, all other paragraphs got calculation greater than 3.00 and the levelof significance is less than 0.05 that is statistically significant. The replaced paragraph No. 31 first ranks with the mean 4.15 , followed by paragraph number 34 in second place with a mean of 3.78 and the paragraph No. 33 ranked third and last paragraphs all arestatistically acceptable.

Paragraph No. 35 got the middle of less than 3.00 and is statistically insignificant.This means that hotel management does not care to involve employees in decisions relating to motivation and reward system. Paragraph No. 32, despite the fact that the arithmetic mean is greater than 3.00, but the significance level was greater than 0.05 is statistically insignificant. This means there is a delay of the need to give material rewards procedures.

The combined paragraphs have got to the middle of account as greater than the 3.00 level of significance and less than 0.05 and are statistically significant. This leads to the acceptance of the hypothesis four.Thismeans there is a motivation and reward performance in Aqaba Hotel. 
Table 5. presents employees' responses to ensure quality of service element in Aqaba Hotel.

\begin{tabular}{|c|c|c|c|c|c|}
\hline No. & $\begin{array}{l}\text { Paragraph } \\
\text { Employee responses to ensure quality of } \\
\text { service }\end{array}$ & $\begin{array}{l}\text { The middle } \\
\text { Arithmetic }\end{array}$ & $\begin{array}{l}\text { Deviation } \\
\text { Normative }\end{array}$ & $\begin{array}{l}\text { The } \\
\text { value } \\
\text { of }(\mathrm{t})\end{array}$ & $\begin{array}{l}\text { The level of } \\
\text { Significance } \\
\text { Spectator }\end{array}$ \\
\hline 35 & $\begin{array}{l}\text { Hotel management is interested to involve } \\
\text { employees in decisions relating to } \\
\text { motivation and reward system. }\end{array}$ & 2.81 & 0.69 & -.116 & 0.00 \\
\hline 36 & $\begin{array}{l}\text { Staff at the hotel are keen to provide the } \\
\text { same high level of quality services }\end{array}$ & 4.13 & 12.51 & & 0.00 \\
\hline 37 & $\begin{array}{l}\text { The hotel management is seeking to have } \\
\text { their hotel is characterized by a level of the } \\
\text { rest of the other hotels }\end{array}$ & 4.35 & 0.58 & 17.08 & 0.00 \\
\hline 38 & $\begin{array}{l}\text { Hotel management is keen to compare the } \\
\text { quality of service provided to guests with } \\
\text { the services of the other hotels in order to } \\
\text { provide better service. }\end{array}$ & 3.96 & 0.84 & 8.53 & 0.00 \\
\hline \multirow[t]{2}{*}{39} & $\begin{array}{l}\text { Taken into account the feedback from staff, } \\
\text { when you make any change or amendment, } \\
\text { intended to provide high quality services }\end{array}$ & 4.00 & 0.51 & 14.57 & 0.00 \\
\hline & Total & 4.11 & 0.60 & 13.25 & 0.00 \\
\hline
\end{tabular}

Fifth hypothesis

It is to ensure the quality of service provided by the Hotel Aqaba. All the paragraphs got calculations as greater than 3.00 and the levels of significance show less than 0.05 i.e. and statistically significant. The replaced paragraph No. 37 was first rank with a mean of 4.35 , followed by paragraph number 36 in second places with a mean of 4.13 , the last paragraph No.38. which ranked the last.

The combined paragraphs have got to the middle of the calculations and are greater than the 3.00 with level of significance less than 0.05 that is statistically significant. The fifth hypothesis is accepted and there is guaranteed quality of service provided by the Aqaba Hotel.

\section{The Study Conclusions}

1) That there is effective support for the management of the hotel due to coordination in the activities of employees.The employees also get help to achieve cooperation among staffand are keen to cooperate with the staff to serve the wishes and needs of guests. Aqaba Hotel seeks to achieve employee loyalty in satisfying ways, and is keen to find a specific context characterized by the hotel for the rest of the other hotels. There is a program to involve staff in training sessions, the applicants being tested before their appointment, and the administration is keen to establish good and lasting relationships with agencies and tourism bodies in order to attract the largest number of guests. Aqaba Hotel also keen on attracting specialized in hotel service staff, and provide all necessary facilities of staff in a program of training courses. The hotel officials cling to personal opinions and impose them on the staff, and not allowed to use water resources efficiently. The employeesdo not use scientific methods to predict the numbers of arrivals and their needs, and also not trained to prevent problems before they occur.

2) Aqaba Hotel is keen for continuous improvement in terms of management, keen to create a quick means of communication and is working to sustain an ongoing basis of encouragement for employees.Aqaba Hotelmakes efforts to improve the quality of service through new initiatives, motivation, continually developed formulas and methods to improve the hotel work. It excludes excess to the procedures are not required.

3) Hotel management arranges parlors, food, rooms, on an ongoing basis. But they do not have enough creations and innovations designed to improve the performance and service at a fair level.

4) The employees and team spirit of empowerment enjoy participation in decision-making, and empowered staff necessary to perform their assigned work. The team spirit prevails between the employees, the colleagues, and staff at the hotel as they can contact supervisors easily. The opinions of staff were in favor of hotel when making important decisions as the hotel is proud of the staff and of proud of their work. The associated staff in the hotel enjoys friendly relations that prevail confidence among them. The management adopts open-door office policy in order to enable employees to put forward their ideas and suggestions for the development of hotel service. The 
staff does not solve the problems encountered without reference to the responsible director, nor is the formation of working teams especially when they are needed to accomplish specific tasks.

5) They motivate employees and reward them for their performance. The employee gets the bonus material when carrying out the completion of a particular job. The hotel is keen on employee appreciation and praises responsible employee at work when the completion of a specific job is done. Bonuses are awarded fairly.But there is a little delay in rewards procedures, and management of the hotel does not bother to involve employees in decisions relating to motivation and reward system.

6) They are ensuring the quality of service offered by the hotel and staff. They are keen to provide a high level quality of service and hotel management seeking to have comparison ofis their quality of services with the rest of the other hotel industry carefully.

7) Management of the hotel trying to compare the quality of service provided to guests with the services of the other hotels for providing good and positive feedback to staff. The staff can use this information when want to make any changes or amendment, intended to provide high quality of services service.

8) There is effective support for the management of the hotel, except that the officials of the hotel cling to personal opinions and impose on staff. They do not use available water resources efficiently, and do not use scientific methods to predict the numbers of arrivals and their needs. Also they do not seek to avoid problems before they occur.

9) It also found that the Aqaba Hotel practiced continuous improvement except that it is not equivalent creations and innovations designed to improve the performance and service at a fair level.

10) Aqaba Hotelenabled and empowered the employee and the teams.The staff are not solving problems encountered without reference to the responsible director, nor is the formation of working teams especially when they are needed to accomplish specific tasks facing them.

11) Aqaba Hotelmotivates employees and rewards them for their performance except for the presence and delay in procedures and lack of interest in the hotel management by involving employees in decisions relating to motivation and reward system.

12) They ensure the quality of services provided by the hotel.

\section{Recommendation and Implications}

1) The study recommends the human resource management to have full responsibilities of people in Aqaba hotel. The city of Aqaba to make it able to identify company training needs in the long term, and to identify individual needs.

2) Human resource department in Aqaba hotel should help in the development of information system for measuring goals through training programs.

3) Overcoming the dealing difficulty, the staff information system should also be implemented to enhance all training programs needed.

4) Management in Aqaba hotel should study the reason of resistance to training programs from some staff to and try to get rid of it.

5) Management with the assistance of HRM personnel should work to make information system available and able to provide periodic or special reports to monitor training effectiveness continuously.

6) Management must work hard to make a competitive program for vacant staff jobs in the Aqaba hotel in Aqaba to be more effective without delay.

7) There is need to use standard tools to monitor working behavior after implementing training programs in Aqaba hotel in the city of Aqaba to compete with other seven star hotels in the city.

8) The study recommended that they should not impose their personal views ofstaff, and they must use available water resources efficiently. They don't use scientific methods to predict the numbers of arrivals and their needs. , They must seek to avoid problems before they occurs, and be innovative to improve the performance and services in a fair level. They should give the opportunity to staff to solve problems encountered without reference to the directly responsible person. They should give them enough and more attention and to especially give opportunity to accomplish specific tasks.

\section{References}

Abdul-Rahim, K. A. H. (2005). Human Resources Management, Dar Wael for Publishing and Distribution, 
Jordan.

Acacia, Z. (2003). The effectiveness of accounting information systems in achieving security, reliability and verification under e-commerce, unpublished $\mathrm{PhD}$ thesis, University of Oman Arabic for graduate studies.

Al-kharabsheh, M. (2010). policy impact on the efficiency of human resources management in public institutions from the viewpoint of managers: Field study, unpublished Master thesis, University of Jordan, Amman, Jordan.

Arthur, J. (1994). Effects of human resource systems on manufacturing performance and turnover. Academy of Management Journal, 37, 670 - 687.

Asafo-Adjei, A. B. (2010), The role of HRIS in strategic human resource management, Master Thesis, pp3.

Bae, J., \& Lawler, J. (2000). Organizational \& Human Resource Management Strategies In Korea: Impact On Firm Performance In An Emerging Economy. Academy of Journal, 43(3), 502-517.

Batt, R. (2002). Managing customer services: human resource practices, quit rates, and sales growth.Academy of Management Journal, 45, 587-97.

Boselie, P., \& Dietz, G. (2003). Commonalities and contradictions in research on human resource management and performance. Paper presented at the annual meeting of the Academy of Management, Seattle.

Denisis, A., \& Griffin, R. (2005). Human Resource Management (2nd Ed.), New York: Houghton Mifflin Company.

Dessler, G. (2003). Human Resource Mnegment 9th edition (Newjersey: Prentice Hall).

Fisher \& others (2003). Human Resource Mnegment: Concepts and Applications 5h editionNew York: Houghton Mifflin Company.

Guthrie, J. P. (2001). High-involvement work practices, turnover, and productivity: Evidence from New Zealand. Academy of Management Journal, 44, 180-19.

Huselid, M. A., \& Becker, B. E. (2000). Comment on "Measurement error on research on human resources and firm performance: How much error is there and does it influence effect size estimates." Personnel Psychology, 53, 835-854.

Ibrahim, A. B. D. (2003). Human performance technology, organizations, foundations and theoretical implications of the Arab environment, the Arab Organization for Administrative Development, Egypt.

Jabber, S. (2011). The impact of environmental factors on the efficiency of internal organizational human resources management functions in the public institution for social security: case study, unpublished Master thesis, University of Jordan, Amman, Jordan.

Lynda, G., et al. (2003). Strategic Human Resources Management : Corporate Rhetoric and Human Reality, New York.

Mayfield, M., Mayfield, J., Lunce, S., (2003). Human resource information systems: a review and model development. Advances in Competitiveness Research, 11,139-151

Mohamed, T. T. (2002). Accounting information systems in evaluation of investment projects, Aitarak for publishing and distribution, Cairo.

Mohammed, I. A.(2002). The impact of the information technology used in Jordanian commercial banks on the efficiency of its financial performance, Master thesis-University of Gezira-Sudan.

Nicky, G. (2004). Strategic human resource management. In Ian Beardwell and Others(Editors), Human Resource Management A Contemporary Apporach,New York,p.41.

Patterson, M., West, M., \& Wall, T. (2000). HRM and Company Performance: A Critique and Some UK Evidence'. Paper presented to the Academy of Management Conference, Toronto, August.

Peccei, R., Guest, D., \& Dewe, P. (2002). Human resource management and organizational performance: a test of universalistic, contingency-based configuration arguments'. Working Paper, the Management Centre, King's College London.

Persian, K. (2006). The impact of human resource management functions in achieving organizational change at Sultanate Oman central ministries, unpublished Master thesis, University of Jordan, Amman, Jordan.

Walter, A. (2003). Strategic Information \& Strategic Decision Making: the FIS/CEO, Interface in Simaller Manufacturing Companies, information \& Management. 
Zahi, B. M., \& Mohamed, C. S. (2005). Training as a key to the development of human resources ingredients, paper presented within the International Forum on Human Development and opportunities for integration in the knowledge economy and human competencies 2005 and Rqlh- ALGIERS.

\section{Copyrights}

Copyright for this article is retained by the author(s), with first publication rights granted to the journal.

This is an open-access article distributed under the terms and conditions of the Creative Commons Attribution license (http://creativecommons.org/licenses/by/4.0/). 